\title{
Examination on the Physical Properties of Untreated Kenaf Insulation Paper at Different Beating Degrees
}

\author{
Muhammad Umair ${ }^{1}$, Norhafiz Azis ${ }^{2}$, Rasmina Halis ${ }^{3}$, Jasronita Jasni ${ }^{4}$ \\ ${ }_{1,2,4}$ Advanced Lightning and Power Energy Research (ALPER), Centre for Electromagnetic and Lightning Protection \\ Research (CELP), Faculty of Engineering, Universiti Putra Malaysia, Malaysia \\ ${ }^{2}$ Institute of Advanced Technology (ITMA), Universiti Putra Malaysia, Malaysia \\ ${ }^{3}$ Department of Forest Production, Faculty of Forestry, University Putra Malaysia, Malaysia
}

\begin{tabular}{|c|c|}
\hline Article Info & ABSTRACT \\
\hline Article history: & \multirow{5}{*}{$\begin{array}{l}\text { This paper examines the physico-mechanical properties of untreated kenaf } \\
\text { based insulation paper with consideration on different beating degrees. Kenaf } \\
\text { bast fibers were first processed through soda pulping process. Different } \\
\text { beating degrees were subjected to the processed pulps. Physical parameters } \\
\text { of the paper were measured for each of the beating degrees. It is found that as } \\
\text { the beating revolution increases, the kenaf based insulation paper's density, } \\
\text { tensile index and burst index increase while thickness and tear index } \\
\text { decrease. }\end{array}$} \\
\hline Received May 1, 2019 & \\
\hline Revised Jul 2, 2019 & \\
\hline Accepted Jul 16, 2019 & \\
\hline Keywords: & \\
\hline
\end{tabular}

insulation paper

kenaf fibers

physical properties

\section{Corresponding Author:}

Muhammad Umair,

Department of Electrical Engineering,

43400 Serdang, Malaysia.

Email: umair9926@gmail.com

\section{INTRODUCTION}

Majority of transformers in the power system networks use wood based papers as one of the main insulation systems. Wood based insulation papers are reliable, cost effective and comply with the thermal, mechanical and electrical requirements for application in transformers [1]. Other alternative sources for papermaking can be from non-wood plants such as wheat straws, sugarcane, bamboo, hemp, bagasse, cotton and jute [2]. Non-wood plants have different charateristics of fibers. Cellulose extracted from non-wood fibers can be used to produce papers with different properties [2-4]. Kenaf is a non-wood plant, recognized as the source for producing papers and paperboard [6].

Kenaf fibers have been used in different types of other applications such as building/packaging materials, papermaking and composite wood [4-7]. Core and bast fibers are the main components in kenaf plants. The lengh of core fibers are shorter than the bast fibers [4, 8]. The papers used in transformers normally have long fibers which contribute to the high mechanical strength which is essential to withstand any physical movements due to the operation [9]. Generally, the length, chemical composition and cell wall thickness of fibers determine the physical properties of papers [10].

Bast fibers lengths of kenaf plant can be between $2.32 \mathrm{~mm}$ and $2.62 \mathrm{~mm}$ which depend on the age, location and species $[3,4]$. One study shows that the mechanical behaviour of kenaf bast fibers is quite close to wood fibres. Furthermore, it is shown that the tear resistance of kenaf bast fibers can be higher than wood fibers. Core fibers are short and contains $60 \%-65 \%$ of the plant by weight. The length of core fibers can be in between $0.5 \mathrm{~mm}$ and $0.7 \mathrm{~mm}$ [4]. The physical properties of kenaf based paper can be further improved 
through processes such as identification of the best pulping method, optimisation of pulp conditions and chemical additives [26].

Beating process is known as one of the basic process in the papermaking. It is a physical treatment on pulps that can increase the contact area between fibres and flexibility by increasing surface area through fibrillation [11, 12]. As a result, the physical properties of the paper can be improved [7, 13]. This paper presents the investigation on the properties of untreated kenaf bast fibers based paper for application in transformers. The process to develop the paper is presented and its physical properties at different beating degress are discussed.

\section{EXPERIMENTAL SETUP}

\subsection{Raw Material}

The raw kenaf bast fibers were obtained locally. First, the fibers threads were separated and cleaned. The next process was to cut the fiber threads into $10 \mathrm{~cm}$ in length. For the pulping process, $1 \mathrm{~kg}$ of Oven Dried (OD) fibers were processed. The OD weight of fibers was calculated after it was dried in the air circulating oven. Image of kenaf bast fibers as shown in Figure 1.

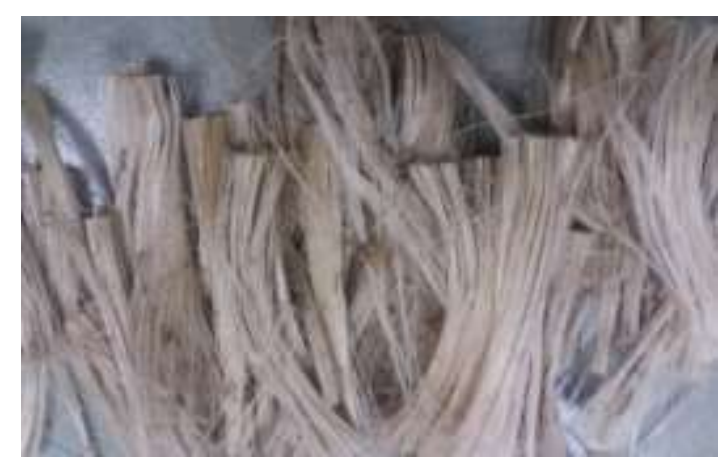

Figure 1. Image of kenaf bast fibers

\subsection{Pulping Process}

Soda pulping process was employed to treat the kenaf fibers through rotary digester. The pulping parameters can be seen Table 1 [14]. The concentration of sodium hydroxide $(\mathrm{NaOH})$ was $14 \%$ with liquor to wood ratio of $7: 1$. The initial temperature was set to $35^{\circ} \mathrm{C}$ with a constant rise up to $170{ }^{\circ} \mathrm{C}$ at maximum time of 120 mins at pressure of 140 psi.

Table 1. Soda Pulping Parameter

\begin{tabular}{cc}
\hline Process variables & Values \\
Liquid/wood fraction & $7: 1$ \\
\hline NaOH $(\%)$ & $14 \%$ \\
Starting temperature $\left({ }^{\circ} \mathrm{C}\right)$ & 35 \\
Maximum Temperature $\left({ }^{\circ} \mathrm{C}\right)$ & 170 \\
Pressure $(\mathrm{psi})$ & 140 \\
Time to maximum temperature $(\mathrm{min})$ & 90 \\
Time at maximum temperature $(\mathrm{min})$ & 120 \\
\hline
\end{tabular}

A hydropupler was used to process the softened kenaf pulps by removing the black liquor residues from the pulp. After separation of black liquor from fibers, the pulps still contain coarse fibers, dirt, bark pieces and digester brick which can be removed by screening process. PTI Summervile fractionators with slot size of $0.15 \mathrm{~mm}$ was used to screen the kenaf pulps in accordance to TAPPI T275 [15]. A centrifugal separator was used to loose pulp with excess water. Then, the pulp was stored in chiller at $6^{\circ} \mathrm{C}$. The percentage of yield was determined based on 1 .

$$
\text { Yield }(\%)=\frac{\text { Weight of screened pulp }(g)}{\text { Weight of raw material }(g)} \times 100
$$


Freeness of pulp was determined based on L\&W CSF tester according to TAPPI T227 in order to determine the surface conditions and swelling of fibers [16].

\subsection{Beating Method}

Screened pulps were exposed to the beating procedures by NORAM PFI mill in accordance to TAPPI T248. The beating process affects the surface area, flexibility of fibers and bonding which lead to the increment of physico-mechanical properties. The beating interval chosen for the study was from 3000 revolutions to 12000 revolutions [17]. The control sample was the unbeaten pulp.

\subsection{Handsheets Preparation}

The handsheets were formed based on TAPPI T205, with a grammage of $60 \mathrm{~g} / \mathrm{m}^{2}$ [18]. Dilution of $24 \mathrm{~g}$ of OD pulps was carried out with 2 litre of distilled water at room temperature as shown in Figure 2. The fiber bundles were dispersed at 50,000 revolutions by a standard disintegrator to relax the fibers and remove latency. The sample was homogenized in stock-divider filled with 8 liters of distilled water. The sample was agitated to ensure proper mixing.

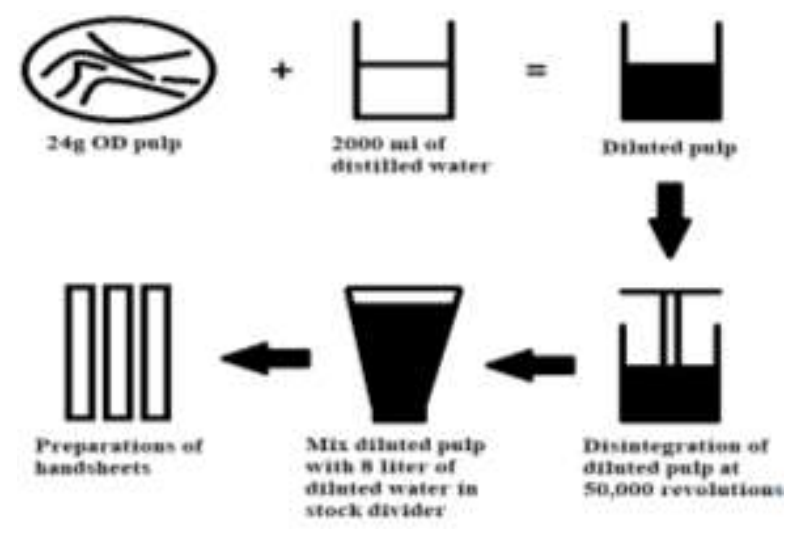

Figure 2. Papermaking process

\subsection{Grammage of Paper}

L\&W micrometer was used to measure the thickness of the beaten paper based on TAPPI T411 as seen in Figure 3 [19]. The grammage of the paper was determined based on TAPPI T410 [20]. As shown in (2) was applied to calculate the apparent density of the paper [21].

$$
\text { Apparent Density }=\frac{\text { Grammage }}{\text { Thickness }}
$$

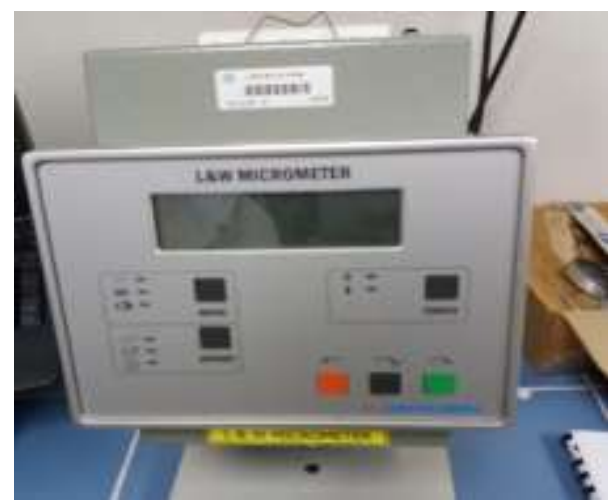

Figure 3. L\&W micrometer 


\subsection{Tensile, Bursting and Tear Resistance of Paper}

Fiber mechanical properties, dimension, structure and bonding affect the zero-span tensile strength of the paper [22, 35, 36]. Buchel B.V Horizontal tensile tester was used to measure zero-span tensile strength of the beaten paper based on TAPPI T494 [22]. As shown in (3) was used to calculate Tensile Index (TI).

$$
T I=\frac{\text { Tensile Strength }}{\text { Grammage of Paper }}(\mathrm{Nm} / \mathrm{g})
$$

The burst strength is the highest hydrostatic force that is required to cause the fracture of the paper [23]. Continuous rising stress was implemented through the burst tester by a rubber diaphragm on the paper orbicular area of $30.5 \mathrm{~mm}$. The burst strength of the beaten paper was measured in accordance to TAPPI T403 [23]. The Burst Index (BI) was determined based on (4).

$$
B I=\frac{\text { Burst Strength }}{\text { Grammage of Paper }}(\mathrm{kPa} / \mathrm{g})
$$

The tear resistance is the force needed to tear the paper. In this study, the tear resistance of the beaten paper was determined using Elmendorf tearing tester based on TAPPI T414 [24]. The Tear Index (TeI) was determined based on (5).

$$
\text { TeI }=\frac{\text { Tear Strength }}{\text { Grammage of Paper }}(\mathrm{mN} / \mathrm{g})
$$

\section{RESULT AND DISCUSSION}

\subsection{Pulp Properties}

The screened kenaf pulps are shown in Figure 4. The pulp yield depends on the lignin compositions, pulping conditions and fiber quality [25]. Generally, a good pulping process should produce high pulp yield [26]. The soda pulping process produces $59.17 \%$ of yield of the kenaf pulps which is considered a high pulp yield and indicates that pulping process and conditions are good [26].

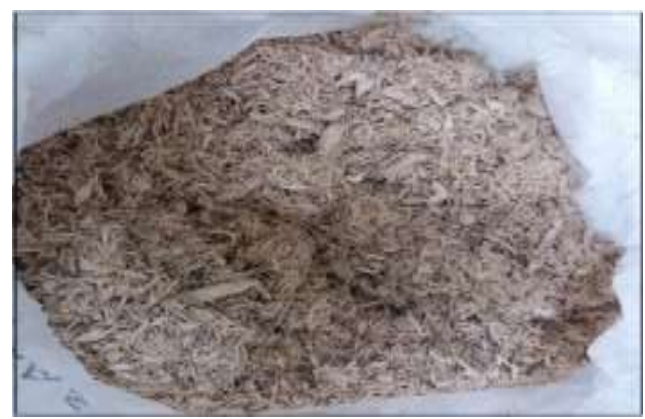

Figure 4. Images of kenaf pulps

\subsection{Physico-Mechanical Properties of Kenaf Paper}

The electrical insulation papers are available in wide range of grammage ranging from $50 \mathrm{~g} / \mathrm{m}^{2}$ to 65 $\mathrm{g} / \mathrm{m}^{2}$ and have different mechanical and electrical characteristics [1]. The grammage of oven dried papers is $60.984 \mathrm{~g} / \mathrm{m}^{2}$ with thickness and apparent density of $175.9 \mathrm{um}$ and $0.3469 \mathrm{~g} / \mathrm{cm}^{3}$ respectively as shown in Table 2. The tensile strength of the unbeaten kenaf paper is $1672 \mathrm{Nm}$.

The unbeaten kenaf paper's tensile index calculated using (3) is $27.417 \mathrm{Nm} / \mathrm{g}$. The conventional insulation papers normally have tensile index greater than $90 \mathrm{Nm} / \mathrm{g}[27,28,29]$. The tensile index of kenaf paper is much lower than the conventional insulation paper which can be improved by modification of pulp fibers and addition of different chemicals [29]. 
Table 2. Physico-Mechanical Properties of Kenaf Paper for Unbeaten Pulp

\begin{tabular}{cc}
\hline Physio-Mechanical Parameter & Values \\
\hline Thickness $(\mathrm{um})$ & 175.9 \\
Grammage $\left(\mathrm{g} / \mathrm{m}^{2}\right)$ & 60.984 \\
Apparent Density $\left(\mathrm{g} / \mathrm{cm}^{3}\right)$ & 0.3469 \\
Tensile strength $(\mathrm{Nm})$ & 1672 \\
Tensile index $(\mathrm{Nm} / \mathrm{g})$ & 27.417 \\
Tear resistance $(\mathrm{mN})$ & 1007.5 \\
Tear index $(\mathrm{mN} / \mathrm{g})$ & 16.52 \\
Burst strength $(\mathrm{kPa})$ & 88.3375 \\
Burst index $(\mathrm{kPa} / \mathrm{g})$ & 1.448 \\
Folding endurance $(\mathrm{No})$. & 6 \\
\hline
\end{tabular}

\subsection{Effect of Beating on Freeness of pulp}

The freeness of the kenaf pulp decreases almost linearly with the increment of beating revolution as shown in Figure 5. The freeness of unbeaten kenaf pulp is $718 \mathrm{ml}$ and it decreases to $54 \mathrm{ml}$ after subjected to 12000 revolutions. The decrement of freeness for the kenaf pulp indicates that there is a fibers development process on the fiber walls. Through beating, the fibers break into multiple fragments which lead to the increment fiber numbers [30]. In addition, low freeness leads to high capability of the paper to hold liquids in the pores and maintain the mechanical strength which are important requirements for the insulation paper [30]. Extremely low freeness is not recommended for high strength of papers.

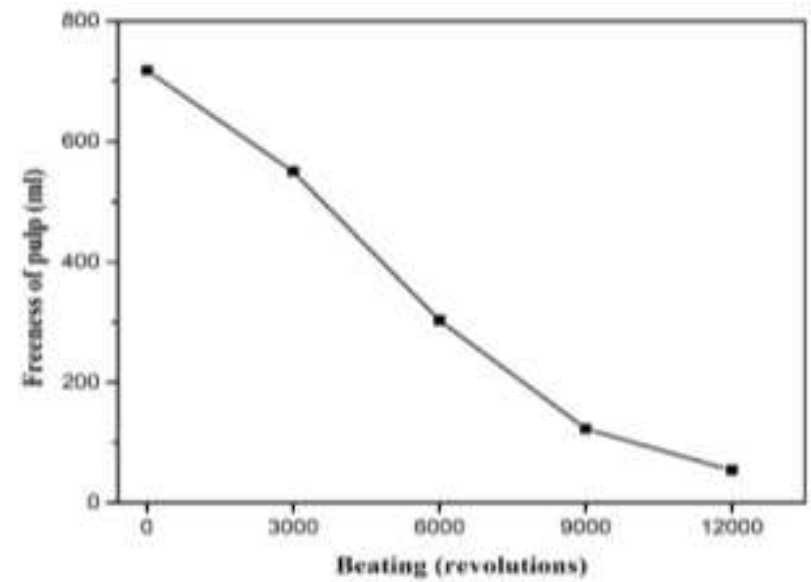

Figure 5. Freeness of pulp at different beating revolutions

\subsection{Effect of Beating on Thickness and Density of Paper}

The beating also has significant effect on the thickness and apparent density of the paper as shown in Figure 6. The thickness decreases from 176 um to 92.99 um after subjected to 12000 revolutions of beating. The density increases while the thickness decreases with the increment of the beating revolution. Beating causes the increment of fibers flexibility and surface area [31]. As a result, the bondings between fibers increase and lead to the increment of fibers joints. Due to this phenomenon, the density of paper increases and at the same time leads to the decrement of the thickness of paper [32]. The conventional insulation papers have densities between between 0.75 and $0.90 \mathrm{~g} / \mathrm{cm}^{3}$ while the thickness is between 70 um to $100 \mathrm{um} \mathrm{[32].} \mathrm{The} \mathrm{range} \mathrm{of} \mathrm{densities} \mathrm{for} \mathrm{the} \mathrm{kenaf} \mathrm{based} \mathrm{paper} \mathrm{are} \mathrm{between} 0.3469$ and $0.6480 \mathrm{~g} / \mathrm{cm}^{3}$ and it is still low as compared to wood-based insulation paper which is $0.8 \mathrm{~g} / \mathrm{cm}^{3}-1.1 \mathrm{~g} / \mathrm{cm}^{3}$ [34]. It is observed that thickness of the kenaf paper decreases up to $53 \%$ while the density of the kenaf paper increase up to $54 \%$ after 12000 revolutions of beating. 


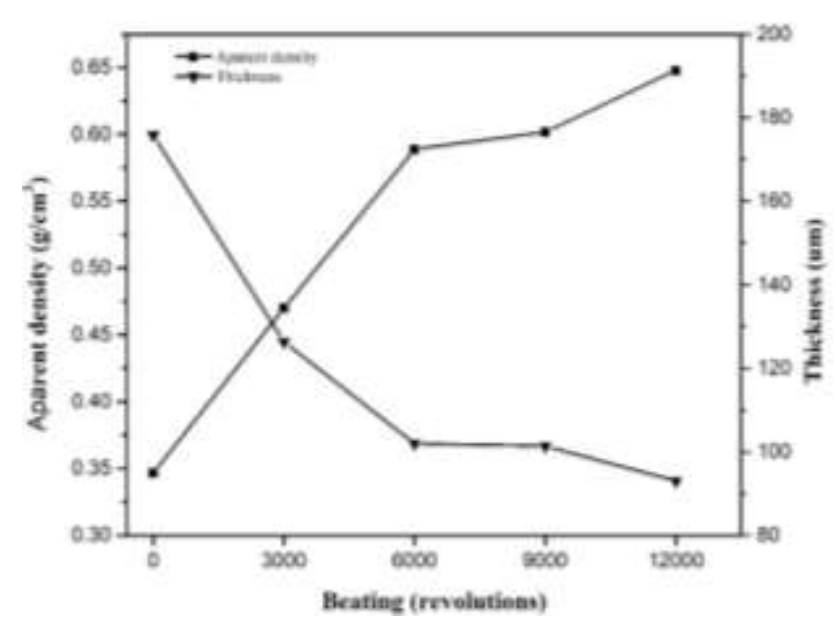

Figure 6. Physical properties at different beating revolutions

\subsection{Effect of Beating on the Mechanical Properties of Paper}

\subsubsection{Tensile Index}

The impact of beating degree on the tensile index of the kenaf paper can be seen in Figure 7 . As the beating revolutions increases to 3000 , the tensile index increases rapidly from $27.417 \mathrm{Nm} / \mathrm{g}$ to $58.19 \mathrm{Nm} / \mathrm{g}$. The rate of tensile index increment for the kenaf paper declines as the beating revolution progresses higher than 3000. After 12000 beating revolutions, the final tensile index of the paper is $72.71 \mathrm{Nm} / \mathrm{g}$. Beating process increases the fiber flexibility and fiber-fiber bonding which causes the tensile index to increase [32]. It is observed that highest percentage of tensile index increment for the kenaf paper is $37 \%$ after 12000 revolutions of beating.

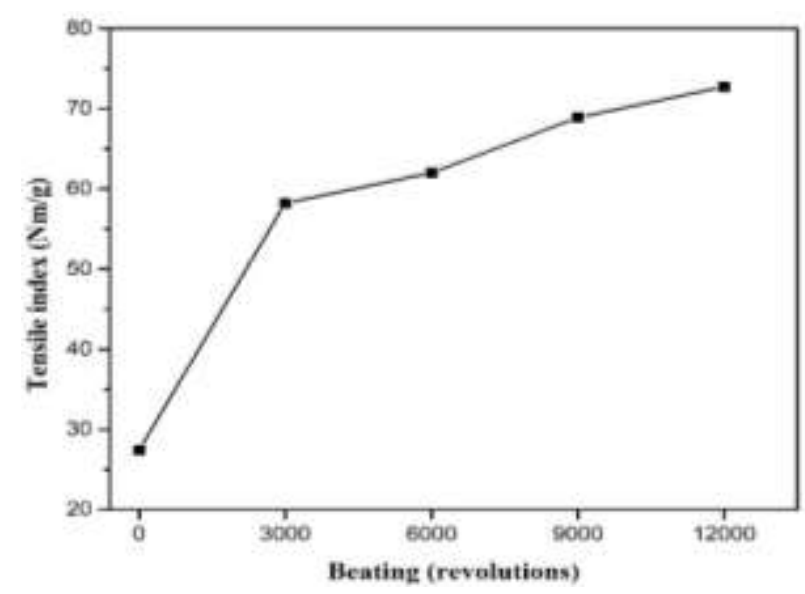

Figure 7. Tensile index at different beating revolutions

\subsubsection{Burst Index}

The increment of beating revolutions causes increment of the burst index as shown in Figure 8. The beating process increases inter-fiber bonding which lead to high burst index [33]. The burst index increases to $4.599 \mathrm{kPa} / \mathrm{g}$ (36\% increment) after 12000 revolutions of beating. 


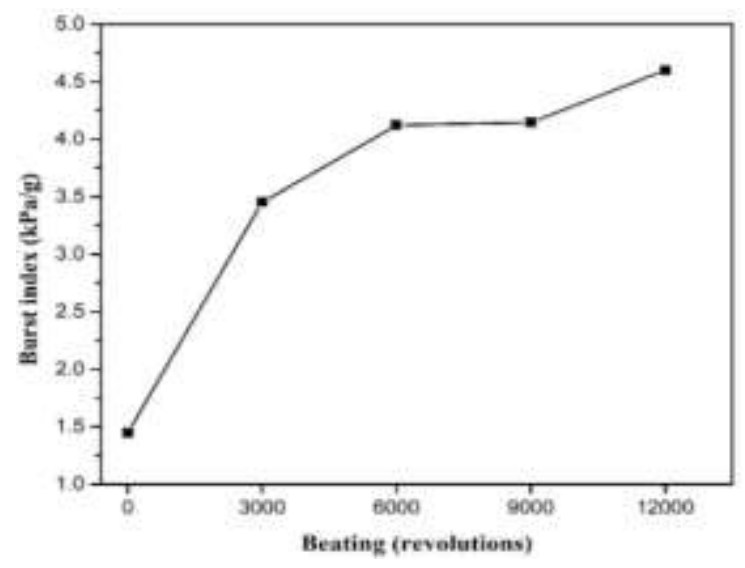

Figure 8. Burst index at different beating revolutions

\subsubsection{Tear Index}

Tear index of the kenaf paper decreases with the increase of bearting revolutions as shown in Figure 9. The beating process results in shorter fibers and hence less bonding area occurred in between fibers. Therefore, less energy is required to tear the paper which lead to lower tear index [33]. It reduces from $16.521 \mathrm{mN} / \mathrm{g}$ to $7.487 \mathrm{mN} / \mathrm{g}$ (45\% decrement) after 12000 revolutions of beating.

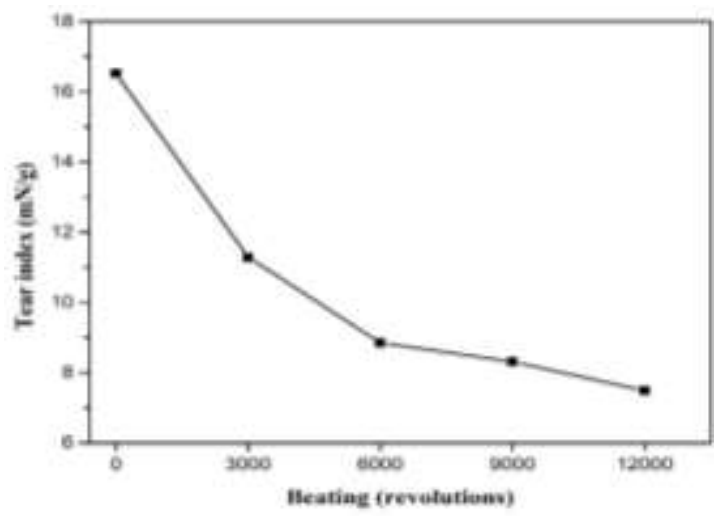

Figure 9. Tear index at different beating revolutions

\section{CONCLUSION}

The beating process enhances the mechanical stability of the paper by increasing tensile index of the paper. The apparent density, burst index and the tensile index of the beaten paper increase by $37 \%, 35.5 \%$, and $53.53 \%$ respectively. The tear index and the thickness decrease by $45.31 \%$ and $52.8 \%$ respectively. The investigation on the improvement of the physical characteristics of the paper can be performed in the future through chemical treatment.

\section{ACKNOWLEDGMENT}

The research was financed by PUTRA IPS (GP-IPS/2016/ 9503000). The authors would like to show gratitude to pulp and paper laboratory, Forest Research Institute Malaysia (FRIM) for research facilities and assistance.

\section{REFERENCES}

[1] Emsley, A. "The kinetics and mechanisms of degradation of cellulosic insulation in power transformers", Polym. Degrad. Stab, vol. 44, pp. 343-349, 1994.

[2] Hammett, A.L., Youngs, R.L., Sun, X.F., and Chandra, M. "Non-Wood Fiber as an alternative to wood fiber in China's Pulp and Paper Industry," Holzforschung, vol. 55(2), pp. 219-224. DOI :10.1515 /HF.2001.036, 2001.

Examination on the Physical Properties of Untreated Kenaf Insulation Paper... (Muhammad Umair) 
[3] Arsène, M.-A., Bilba, K., Savastano Jr, H., \& Ghavami, K. "Treatments of nonwood plant fibres used as reinforcement in composite materials", Materials Research, vol. 16(4), pp. 903-923, 2013.

[4] Shakhes. J., Rezayati-Charani, P., and Zeinaly, F. "Evaluation of Harvesting Time effects and cultivars of Kenaf on Papermaking," BioResources, vol. 5(2), pp. 1268-1280.

[5] Sabharwal, H.S. "Biomechanical pulping of kenaf," TAPPI Journal, vol. 77(12), pp. 105-118, 1994.

[6] Han, J.S., Miyashita, E.S and Spielvogel, S.J. 1999. "Properties of kenaf from various cultivars, growth and pulling conditions, In Kenaf Properties," 1999.

[7] Wise, L.E., Murphy, M., D'Adieco, A, "A chlorine holocellulose, its fractionation and bearing on summative wood analysis and studies on the hemicellulose," Paper Trade Journal, vol. 122(2), pp. 35-43.

[8] Pande H., Roy D.N., "Delignification kinetics of soda pulping of kenaf," J. Wood Chem. Technol, vol. 16(3), pp. 311-325, 1996.

[9] Mazuki AAM, Akil HM, Safiee S, Ishak ZAM, Bakr AA. "Degradation of dynamic mechanical properties of pultruded kenaf fiber reinforced composites after immersion in various solutions," Composites Part B, vol. 42(1), pp. 71-6, 2011.

[10] Ruijin Liao, Shuaiwei Liang, Caixin Sun, Lijun Yang and Huigang Sun, "A comparative study of thermal aging of transformer insulation paper impregnated in natural ester and in mineral oil," European Trans. Electr. Power, Vol. 20, pp. 518-533, 2010.

[11] Raymond AY, Rowell RM, Cellulose structure, modification and hydrolysis, John Wiley and Sons, Inc, New York, 104-8, 1986.

[12] Suphat, K. "Preliminary Study of Anthraquinone in Sweet Bamboo (Dendrocalamus asper Backer) Alkaline Sulfite Pulping," Chiang Mai J. Sci, vol. 34(2), pp. 235-247, 2009.

[13] Biermann, C. J., Essential of pulping and papermaking, California: ACADEMIC PRESS, Inc, 1993.

[14] Harsnal, P., Delignification Kinetics of Soda Pulping of Kenaf. Journal of Wood Chemistry and Technology, vol. 16, pp. 311-325, 1997.

[15] TAPPI T 275, Screening of Pulp, The Technical Association of Pulp and Paper Industry, USA,

[16] TAPPI T 227, Freeness of Pulp, The Technical Association of Pulp and Paper Industry, USA,

[17] TAPPI T 248, Laboratory beating of pulp, The Technical Association of Pulp and Paper Industry, USA,

[18] TAPPI T 205, Forming Handsheets for physical tests of pulp, The Technical Association of Pulp and Paper Industry, USA.

[19] TAPPI T 410, Grammage of paper and paperboard, The Technical Association of Pulp and Paper Industry, USA,

[20] TAPPI T 411, Thickness of paper and paperboard, The Technical Association of Pulp and Paper Industry, USA,

[21] ISO 534, Determination of thickness, density and specific volume, International Organization for standardization, Switzerland, 201.

[22] TAPPI T 494, Tensile properties of paper and paperboard, The Technical Association of Pulp and Paper Industry, USA.

[23] TAPPI T 403, Bursting strength of paper, The Technical Association of Pulp and Paper Industry, USA,

[24] TAPPI T 414, Internal Tearing Resistance of Paper, The Technical Association of Pulp and Paper Industry, USA.

[25] Jose C. del R1o, Ana Gutierrez, Marina Hernando, "Determining the influence of eucalypt lignin composition in paper pulp yield using Py-GC/MS," J. Anal. Appl. Pyrolysis, vol. 74, pp. 110-115, 2005.

[26] Halis, R., "Optimization of Kraft and Biokraft Pulping for Kenaf V36," Ph.D. Thesis, Universiti Putra Malaysia, Serdang, Selangor, Malaysia, 2011.

[27] D. H. Shroff and A. W. Stannett, "A Review of Paper Aging in Power Transformers", IEE Proc., vol. 132, Part C, pp. 312-319, 1985.

[28] E.L. Morrison, "Evaluation of the thermal stability of electrical insulating paper", IEEE Trans. Elect. Insul. vol. 13(3), pp. 76-82, 1968.

[29] W.A. Wink, K. Ward, Jr., and H.A. Swensen, "Improving the thermal stability of paper by chemical modification," Tappi, vol. 51(10), pp. 155-158.

[30] Broughton, G. and Matlin, N.A., "The mechanical behavior of paper-Part I," Tappi, vol. 34(11), pp. 493-497, 1951.

[31] Cox, H.L., "The elasticity and strength of paper and other fibrous materials," British Journal of Applied Physics 3, 72-78, 1952.

[32] Elyas Afra, Hossein Yousefi, Mohamad Mahdi Hadilam, Takashi Nishino, "Comparative effect of mechanical beating and nanofibrillation ofcellulose on paper properties made from bagasse and softwood pulps," Carbohydrate Polymers, vol. 75, pp. 725-730, 2013

[33] Yusoff, M.N.M., Kadir, A. Abd., \& Mohamed, A. H, Utilization of Bamboo for Pulp and Medium Density Board, In Proceeding of Seminar Towards the Management, Conservation, Marketing and Utilization of Bamboos, Kuala Lumpur: FRIM, 196-205.

[34] Michael Franchek, Aleksandr Levin, "Insulations DPEI," Transformers Magazine, Vol. 3(2).

[35] Muhammad Umair, Norhafiz Azis, Rasmina Halis, Jasronita Jasni., "Investigation on the Effect of Beating on the Physical and Mechanical Properties of Untreated Kenaf Based Insulation Paper," 5th IEEE International Conference on Smart Instrumentation, Measurement and Applications, Songkhla, Thailand 28-30 November 2018, Songkhla, Thailand.

[36] Ramani, A. N., Ariffin, A. M., Vijian, G., \& Ghani, A. B. A., "The effects of nano fillers on space charge distribution in cross-linked polyethylene," International Journal of Electrical and Computer Engineering, vol. 7(6), 3147, 2017. 